\title{
Can One Drink Informal Water Alternatives Directly? Using Mobile Phone to Establish Trust in Quality
}

\author{
Elisha Akech Ochungo ${ }^{*}$, Gilbert Ong'isa Ouma ${ }^{2}$, John Paul Odhiambo Obiero ${ }^{3}$, \\ Nicodemus Abungu Odero 4
}

\author{
${ }^{1}$ Institute for Climate Change and Adaptation (ICCA), University of Nairobi, Nairobi, Kenya \\ ${ }^{2}$ Department of Meteorology, University of Nairobi, Nairobi, Kenya \\ ${ }^{3}$ Department of Environmental and Biosytems Engineering, School of Engineering, University of Nairobi, Nairobi, Kenya \\ ${ }^{4}$ Department of Electrical and Electronics Engineering, Machakos University, Machakos, Kenya \\ Email: *elishakech1@gmail.com
}

How to cite this paper: Ochungo, E.A., Ouma, G.O., Obiero, J.P.O. and Odero, N.A. (2019) Can One Drink Informal Water Alternatives Directly? Using Mobile Phone to Establish Trust in Quality. Journal of Water Resource and Protection, 11, 1260-1277.

https://doi.org/10.4236/jwarp.2019.1110073

Received: September 13, 2019

Accepted: October 9, 2019

Published: October 12, 2019

Copyright $\odot 2019$ by author(s) and Scientific Research Publishing Inc. This work is licensed under the Creative Commons Attribution International License (CC BY 4.0).

http://creativecommons.org/licenses/by/4.0/

\begin{abstract}
The informal water market in cities within the Global South is expanding, thanks to drought associated water shortage challenges and other socio-hydrological factors. A midst the growth is the inherent information signal asymmetry driven mainly by the vendors' unwillingness to share the actual quality data of their source water with their customers. As a result a big mistrust environment has been created as currently; the customers have no mechanism to verify the water quality in real time. This paper aimed at developing an android application software system to fill the gap. The system is to operate the water vending business landscape as a trusted social network site (SNS) using handheld mobile phone devices. An Agile-Scrum methodology was utilized as it allows for quick changes to the system as necessary. An android platform was chosen as the initial Operating System (OS) to run the software system due to its faster global outreach capability. Specifically, Android Studio 3.4.2 IDE running on Windows 10 was deployed. And the primary languages used within the IDE were; Kotlin for the functionality and XML for the user interface (UI). Additionally, the Firebase SDK tools were used for cloud-based database functionality. The results of the prototype include; user side access and feedback exchanges, backend side supports and other added functionalities. The paper is of the strong view that since the system works on anytime-anywhere modality, then it is possible that one can drink the informal water directly. The system is recommended for full scale trial in the affected cities.
\end{abstract}

\section{Keywords}

Signal, Informal Water, Quality, Trust, Android Application, Drink 


\section{Introduction}

Information exchange in a market place usually precedes any actual transaction event between two parties with shared common interest over a product. The product owner is normally the one who initiates the flow of the messaging by way of creating the product's visibility using a number of methods to a potential buyer. This phenomenon is known as information signaling, which has been investigated for a long time in many markets [1] [2]. It refers to a practice whose primary purpose is to "signal" or convey some message about a product to a buyer speculatively [3]. Signaling plays a crucial role in every social exchange [4] [5] like; in the hiring of new employees within the labor market [6], in human marriages; from courtship to divorce [7] [8] [9] [10] [11], in wild animals' mate selection processes [12] in wild animal protective adaptation in their habitats [13] [14], in consumer goods' quality detection initiatives [15] et cetera.

As a term, signaling is used as a proxy indicator meant to display the nature and attributes of a product to a buyer transparently or not, depending on the intention of the sender. In reality, signaling has a bi-directional flow of communication; one being the sender and the other the recipient. In a number of cases, a signal's purpose is to alert a buyer/receiver on the state of quality of a "good" presented for sale [16]. In sum, it basically helps to establish trust which further goes to aid in purchasing choice decisions by a potential buyer on a set of goods of varying qualities in a market [17] [18] [19]. The credibility of signals is linked to the sender's vulnerability to receiver's sanctions. If the promised quality is false, the sender will lose its reputation and will put his expected gains at risk [20].

In some instances however, the seller may hide the real "information" from the buyer thereby creating information asymmetry, especially if the quality is somewhat inferior [21] leading to a state of fraudulent market behavior. This skewed messaging phenomenon was first discovered by George Akerlof in his assessment of market for "lemons" in the United States of America [22]. The seminal work by Michael Spence pioneered the correction of information asymmetry in the employee-employer hiring exchanges by proposing to have the advantaged party send a signal that reveals some piece of relevant information to his/her counterpart [23]. In the water market for instance, the conventional access to safe and good quality water is via the municipal water supply system [24] [25]. Today however, the urban water market landscape is fraught with quality doubt forcing many a consumer to obtain drinking water from sources other than the tap [26].

In the developed nations, health risks; both real and perceived, are often the main reason why people use water from vendors as a source of drinking water [27]. Again, in certain instances, you may find that the municipal taps sometimes run dry due to drought impacts [28] as reported in the lesson notes from California's 2012-2016 drought. In the developing nations on the other hand, especially those from the sub Saharan Africa region, the public water supply sys- 
tem is often impaired by the inefficient nature of operational management practices [29] [30] besides other social and hydrological uncertainties [31].

To survive during such dry seasons, consumers do depend on water delivered by push carts, water tankers, jerry cans and/or home dug wells [32] [33], a practice known as water vending. The source quality of these vended water alternatives is uncertain, only vaguely known to the water vendors [34]. This means that the consumers (buyers) have no way of verifying the quality of the water delivered [35]. As much as scholars like [36] recently included vendor water supply as part of the integrated water resource management (IWRM) system, the big question which is yet to be answered is; can one drink water from the informal water alternatives directly?

The emergence of informal water supply service is a weak signal for the need for water sector reform. For that reason, this paper proposes for the use of a mobile phone device as a wildcard aimed at establishing trust on quality [37]. And the argument here is that a consumer with such quality information is likely to believe the trustworthiness of the water delivered by a vendor. In other words he/ she will place high foreknowledge value on the delivery [38]. Accordingly, he/she will direct the use based on fit for purpose including for drinking needs. The intriguing condition however, is that, it is nearly impossible to codify or give identity to water source since water quality characteristic, as it were, is enigmatic.

This paper has drawn inspiration from the anthropometric technique work designed by the French criminologist, Alphonse Bertillon in 1879 [39]. Bertillon developed a system describing individuals on the basis of catalogues of physical measurements [40] [41]. Using the framework of the identity database he built, this paper aims to create a water quality bertillonage akin to what [42] formed for the information communication technology software's market. By this, it is projected that water quality provenance tracking will be made easier for all consumers. The rest of the paper is organized thus; Section 2 presents theory of information signaling and the evolution of android applications in water sector, Section 3 outlines the method, Section 4 presents results and discussion, while Section 5 is conclusion.

\section{Theory}

\subsection{Information Signaling}

The contribution of informal water market to the provision of water supply security is commendable [43]. The gap to fill however is the management of quality information disclosure as was done for the case of restaurants by [44] [45]. The issue of quality information signaling and disclosure has attracted contribution from eminent scholars like the one in [46] who wrote a book titled "blacked out: government secrecy in the information age". This seminal work motivated more work on product information disclosures [47]. The pillars of a product's bad or good news representation were laid by [48] [49] [50]. Information dis- 
closure do fall in categories such as; mandatory, voluntary and third party certification [51] [52]. Disclosures do give quality assurance through product; branding, trademarks and/or accreditation, all being symbols of trust [53].

The theory of quality information disclosure has however two opposing strands in literature; that is, the seller's incentive [54] and the third party certifier's interest [55] [56]. Despite this negative dichotomy, the bottom line is that signals hold the way and manner of information exchange [57]. By extension, once the customer gets convinced that he/ she is safe, then he/she begins to behave not by rules and codes but by trust; itself being a moral prejudice [58]. This is the language used by marriage brokers [59], skilled worker on job interview [60] and trans-generational knowledge transfer in traditional societies [61]. Nonetheless, honesty is very hard to achieve in most of these interactions [62].

In an endeavor to signal an honest image of a product, marketers have used pricing [63]-[69]. Others have used advertisements [70] [71] [72]. Separately, another set of marketers have tried customer referrals [73] [74]. While some organizations have always used innovative trading practices such as warranties [75], fair trade methods [76], goods labeling and/or branding [77] [78], product certification [79] [80] [81], eco-labeling [82], agent contracting [83] [84] [85] and use of middlemen [86].

\subsection{The Evolution of Android Applications in Water Quality Disclosures in Cities}

Most cities in poor countries face water shortage challenges perennially. As a way of coping with this inadequacy, the inhabitants usually depend on the informal water market supplication [87], the inherent distrust they hold in quality notwithstanding. This doubt is borne out of the fact that, currently, the vendor water business' landscape lacks a reliable mechanism to allow for the verification of the originality of the water sources.

Additionally, the credence nature of water as a "good" also contributes more to the negative perception on safety risk. And in a normal condition, it is usually not easy for a customer to judge the technical quality of the vendor delivered water. What we often see on many city roads are water tankers whose walls are painted in color blue and a statement that reads; "clean water". This ordinarily is not enough certification to help establish trust and confidence on the vendor water.

Instead, there is a rising need for a properly secured signaling on quality [88]. In order to achieve this goal, it is the position of this paper that hand held mobile phone devises could be of immediate service. It so happens that in cities today, use of smartphones and/or tablets is pervasive. And it is within our common knowledge that these devises are able to provide anytime-anywhere access to information [89]. Consequently, conceptualization on how to establish trustworthiness of the quality of vendor water is possible on the mobile technology infrastructure. This is likely to entrench a positive attitude on the vendor water. At the moment, urban water insecurity has seen the entry of greedy and unethi- 
cal water vending businesses which has by extension opened the door for potential abuses. This happens simply because the vendor water market is mostly unregulated.

However, there are cases where regulations exist but the vendors just choose to engage in malpractices like what [90] reported on Amman city in Jordan. Here, criminal gangs do cut a portion of tanker water in collaboration with operators, as the unsuspecting customers are kept in the dark. Some water vendors are increasingly involved in nefarious activities which end up causing havoc on unsuspecting consumers who depend on them for their daily needs. They are for a fact a common sight in most cities of the global south, where their services are indispensable. A visitor to these cities is always welcome by push carts loaded with jerry cans full of water being delivered to homes.

The quality of the water is however questionable exposing users to waterborne diseases as [91] reported for Dala neighborhood of Kano city, Nigeria. The other challenge is that the vendors obtain their water from a mixture of sources -some improved while others, unimproved. But the actual quality information is always hidden from the customers particularly on the latter sources since vending has become a brisk water business as observed for mai ruwa (Hausa language for water sellers) in Makurdi city, Benue state, Nigeria by [92].

Further, for many of the vendor water customers everywhere, the vendors do complete the cycle of water supply as a virtual piped water network owing to their vulnerability to water shortage stress [93]. The common thread however across the water vending enterprise is the conniving behavior regarding the concealment of actual water quality to their customers whose consequences are dire. An interesting case is reported by worker in [94] to the effect that drinking water sold by roadside vendors of Delhi, India is contaminated which has led to high waterborne mortalities. From the above discussion it is clear that fraudulent activities are rampant in supply side which will finally put the authentic water vendors' existence at stake. On the other hand, due to these kind of unchecked fraudulent activities customers will be highly discouraged.

Trust establishment on consumer goods has seen the deployment of user action on social media where actors engage their mobile phones to mine product information [95]. From around the year 2005 when Google Inc. acquired android from Andy Rubin and his colleagues; it has been used as a trust cornerstone in e-commerce. For instance, the various consumer product barcodes have utilized camera devices in mobile phones.

In the other sectors like geology, agriculture, medicine et cetera, android platforms have registered tremendous successes in establishing trust. This is mainly because it is powered by Open Handset Alliance and Google, making it freely accessible to many practitioners. Its Software Development Kit (SDK) which has its own modern user interface framework is an added advantage. This again, is backed up by own optimized Java Virtual Machine (JVM) which does help to counter handheld device limitations such as memory, processor speed and power. 
That is why android popularity has soared from the year 2007 when its use began proper. In the water sector, android application has been used to book water tanker for emergency water distribution [96]. It has also been used by water companies to track water quality results in some rural communities [97]. Other water companies have used it in the form of wireless water flow monitoring [98]. From the foregoing, it is clear that the existing literature on android application in the water sector has focused on a centrally managed system and not on the side of the consumer to enable him/her verifies the quality of water in real time, especially the one from the informal water market. This is the gap the current study is to fill. The main aim of this study therefore is to establish the trust between the consumers and their corresponding water vendors using android run mobile phones. This study contributes to the drinking water trustworthiness in one way: to enable consumers to verify the authentic quality of vendor water at the time of purchasing the informal water alternatives.

\section{Methodology}

\subsection{General}

The development of a Water Quality Tracking System (WQTS) followed a standard iterative process in creating a mobile application named Maji Safi app in line with Agile-Scrum methodology [99]. It all began with the assumption that there exists a deep seated mistrust that water consumers hold on the informal water quality. Stemming from this standpoint, we picturized how to program in terms of; data sources, needed algorithms, features and functions, and levels of risks. The central issue was to understand the propagation of climate change risk in our society today. It occurred to us that the modern day urban water consumer in a developing nation like Kenya is usually exposed to a cascaded water shortage risk levels as outlined in Figure 1.

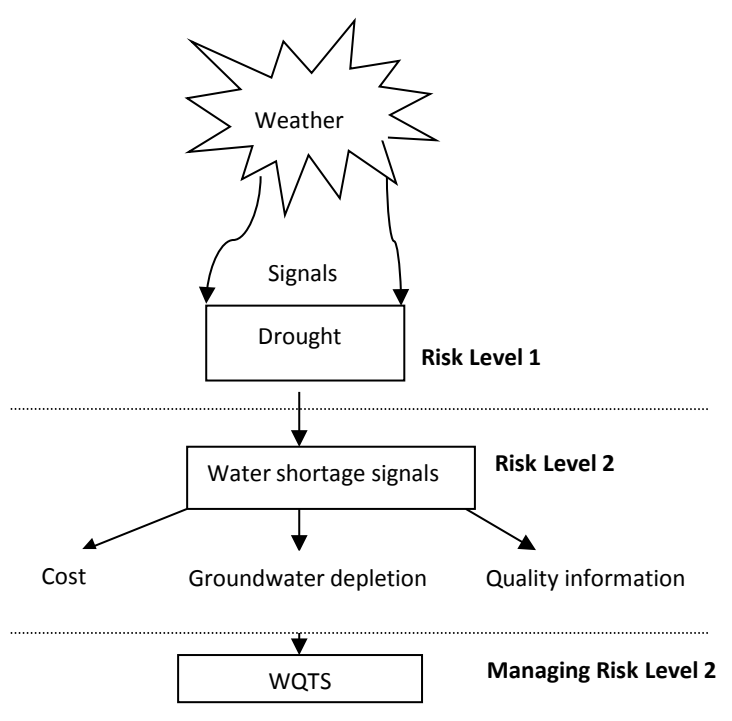

Figure 1. Risk level conceptualization. 
At the apex is the climate variability, manifesting itself in varying signals. For this study, the primary risk signal is taken as drought considered as risk level 1 . This triggers water shortage at the consumer doorstep. And which quickly snowballs into risk level 2 in three ways. One, the high price charged on consumers by the informal water vendors; Two, the intensified and the unregulated groundwater abstraction activities; Thirdly, the asymmetrical information of vendor water quality exchanges. The latter can potentially spread the exposure risk further downwards in terms of health implications on consumers. It is the idea of this study to manage the risk at level 2 using water quality tracking system (WQTS).

For the idealized system, the app functionality was narrowed down to the consumer level. The proposed quality tracking system seeks to mitigate the cost escalation arising from coping with drought induced water shortage events. It also aims to manage the exposure risk arising from the public perception that water from the informal water market is of poor quality. And this it will do by disclosing in a transparent manner by allowing registered water consumers to inquire for such information using the app. The programming began with the outlining of the information flow schematically as illustrated in Figure 2.

\subsection{System Workings}

This paper is limited to how the quality is tacked. Basically, the communication between the server and the holder of mobile phone usually known in communication lexicon as the client; a water consumer or interested agent, is bidirectional. First to be in the system, there will be minimum registration requisites for both the borehole operator and water delivery vendor. This recruitment protocol will fall in the ambit of the water sector quality regulatory agency. The server as the monitoring centre has three critical roles viz;

- User registration and verification;

- Receiving water delivery requests and assigning system generated feedbacks;

- Receiving water quality inquiry request and sending quality feedback for the specifically assigned water source.

The bi-directional exchanges between a water consumer and the server entails; account creation for first time user, login for a continuing account holder, making orders for water delivery, user verification, quality confirmation, order verification through price display and user payment. On the other hand, the communication between server and vendor is similarly bi-directional and consists of; user registration and verification, delivery dispatch and water source quality request. The consumer and vendor then communicate through the delivery of the actual water quantity as per the made request. The transactional records remain stored in the server for future water use planning needs.

This basic model was reviewed repeatedly and a prototype of Maji Safi app was produced, to operate on Google's Android Operating System (OS), version 23 or higher. In the creating of the app we used Google's Android Studio Integrated Development Environment aka IDE ver.3.5 running on windows 10. The 


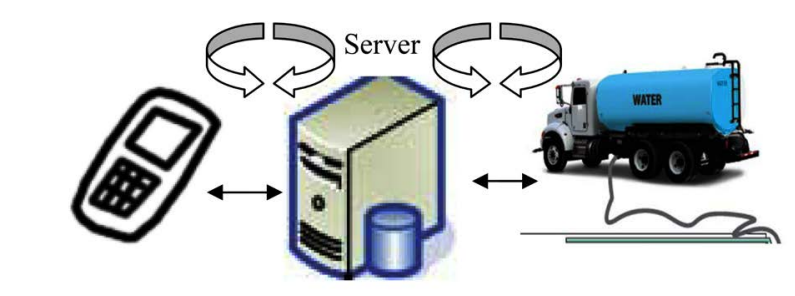

Mobile Phone Transactions

Informal Water Market

Figure 2. Idealized bi-directional communication between server and system users.

primary programming languages used were Kotlin for the app functionality and XML for the app User Interface. Firebase System Development Kit (SDK) was also utilized within the IDE to provide the cloud-based database functionality. The prototype was tested for usability and later modified to refine it through several series of usability tests.

The software has three basic functions:

1) User Registration and Login;

2) User Requests and Feedback;

3) Water quality verification requests and dissemination.

In terms of user experience, the app operates in the English language through prompting messaging. At the moment we have not created a public access system for the prototype. Some of these may include avenues like; Google Play Account, web link and/or cloud based account. For the trial purposes, the set up link to the prototype is;

https://drive.google.com/open?id=1VS8PtN4t73cj-oC_HQGOz_Dim87Y16ua.

Remember, the set up link can only be installed in an android phone. Secondly, the user experience has been made to be simple. Upon installation and to begin operation, the user will be prompted with a command to create an account, preferably using an email address (even a dummy one can work) followed by a request to insert a personal password. It is also important to note that even if the user forgets the first account detail, in the repeat, he/she can create a new account and proceed as before explained above. This prototype is only a proof of concept for water quality tracking in the informal water market. Otherwise for commercial purposes, the app will be made more robustly intelligent in multi-directions for security reasons.

\section{Results and Discussion}

\subsection{User Registration and Login}

A first time user is expected to run the installation setup on an Android phone. His/her next step is to open the app upon which he will be presented login where he's expected to click on the "Create Account" button where and he/she will get redirected to the account creation activity. The user is then expected to enter the details outlined in the available fields, including their email and a suitable password, thereupon after clicking on the "Create Account" button will be redirected 
back to the login activity to login to the system if the account creation was successful. After login the user is then presented with two options: order water or view water quality information see Figure 3: (a) Maji-Safi Launch Screen, (b) Maji-Safi-Login Screen (Seen right after the launch screen) and Maji-Safi Registration Screen (Prompted by clicking the create account button from the Login Screen).

\subsection{User Requests and Feedback}

User request is triggered when a logged in user clicks on the "Request Water" button. The user is then prompted to fill in a form with the amount of water he/she requires and his location coordinates, for the commercial version, the user location coordinates will be system generated. On submission of these details, an invoice is generated providing the cost breakdown of the request, highlighting the cost of the water requested, cost of transportation to the location, and the total amount as a sum of these two.

The user will then be able to check/verify the quality of the water he/she will be receiving and further enter the payment transaction code provided by the mobile money transfer option (e.g. MPESA in Kenya's case) to complete the transaction. The user will from this point wait for the delivery of his/her paid for water, see Figure 4: (a) Maji-Safi: verification notification on successful account creation) automatically redirected back to login screen after successful account creation and (c) Maji-Safi-choose Task screen-choose between making a water request and viewing quality information.

The verification of the water quality is triggered when the user clicks on the "Quality Information" button. The user will then once again be prompted to choose between using a verification code (assigned when making a request for water) where the water quality index (WQI) of a particular source of water (borehole with code "BH" followed with numeric number from "01") can be verified, or to view the water quality index map of the area. These are done by clicking on "Quality Verification" and "Quality Map" respectively. The water quality map is a water quality index contoured map for the operation area which must be developed first by the regulating water quality agency. see Figure 5: (a) Maji-Safi Quality related tasks-redirected on selecting the "Quality Info" button from Choose Task, (b) Maji-Safi Quality Map-displayed on clicking the "Quality Map" button on the Quality Tasks screen, (c) Maji-Safi Source Verification Screen-redirected after clicking on the "Quality Verification" button and (d) Result after clicking the "Submit Code" button.

For confirming order for water delivery upon getting satisfied with the water quality, one will simply enter the quantity in litres. The system will post the price, if in Kenya, this will be displayed in shillings. Separately, the system will generate transport cost. In an ideal sense, if the WQTS is being operated by a company, then the payment will go centrally to the dedicated account from which individual actors will get their accounts credited. 


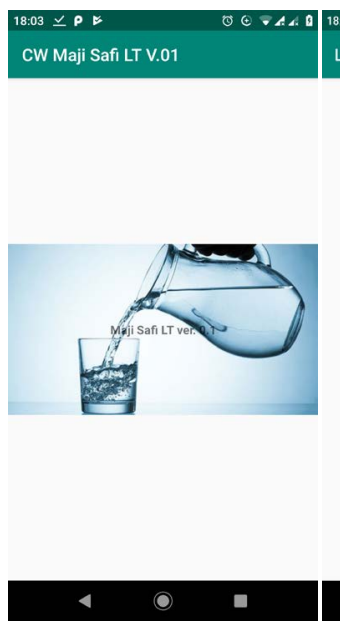

(a)
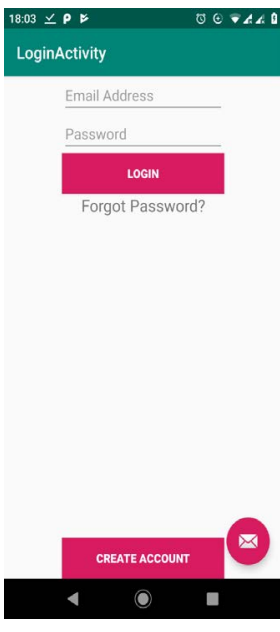

(b)

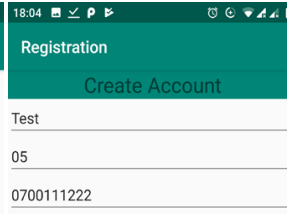

test5@test.com

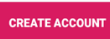

Figure 3. Launch screen.

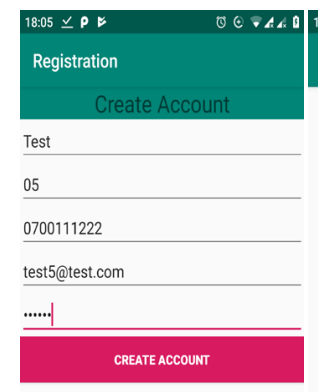

Already Have an Account

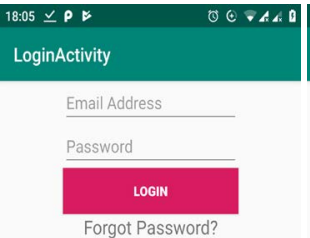

18:07 $\simeq P \vee$

MsChooseTask

(c)

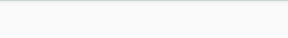

Email Addres

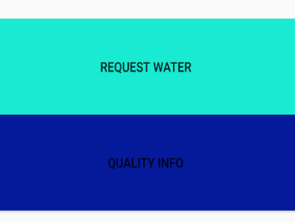

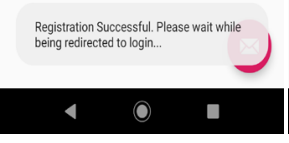

(a)

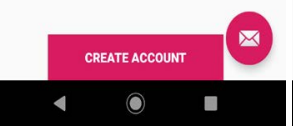

(b)

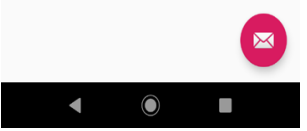

(c)

Figure 4. Completion of account creation.

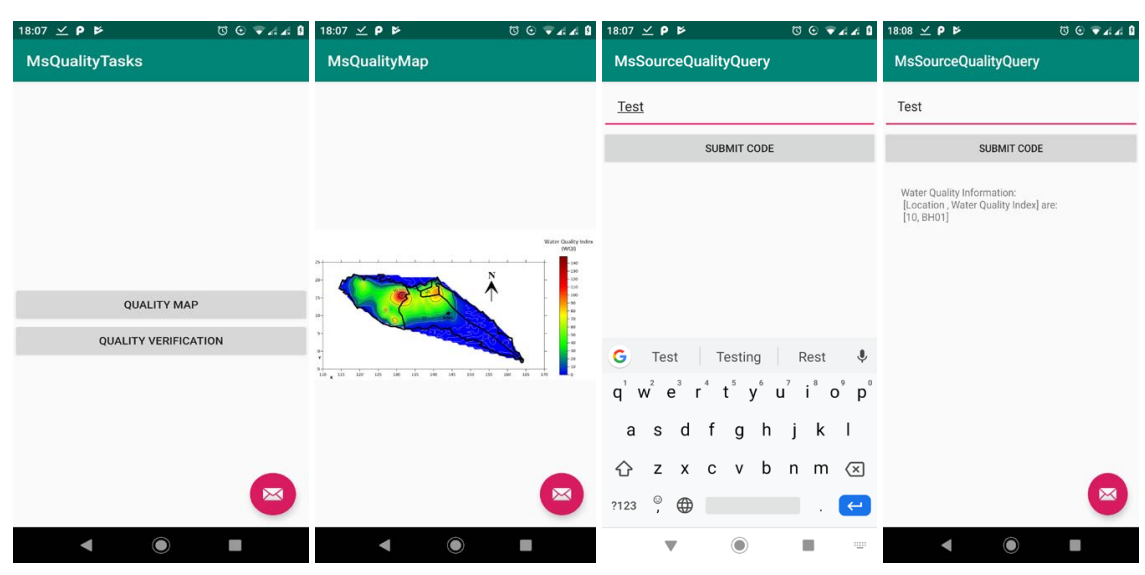

(a)

(b)

(c)

(d)

Figure 5. Quality verification. 
This app is meant to be operated on Blockchain Technology platform which prides in immutability and transparency. This means, no one actor can alter any record, from quality data, orders and financial records unless permission is granted consensually by all actors. For water quality data uploads for instance, the agency in charge will have to broadcast this intention beforehand. The same agency remains accountable for the quality of water delivered through the system. The conveyance truck will be auto-tracked in real time to weed out the temptation for fraudulent acts, see Figure 6: a, b, c, d, e, f and d.

Where (a) Maji-Safi Make Request screen-redirected on clicking Request Water button from the "Choose Task" screen, (b) Input of information-liters required and location coordinates, (c) Generated invoice after assignment of suitable vendor, done on clicking the "Submit" button on the MakeRequest screen, (d) Display of the quality information of the assigned source of water (Displayed on clicking the "Verify Quality of Requested Water" button), (e) Prompt for payment after quality verification of requested water, (f) Entering the transaction code provided by relevant mobile money transfer service provider and (g) Return to main menu (Choose Task screen) on successful upload of request to the cloud database/server and successful completion verification notification from the server.

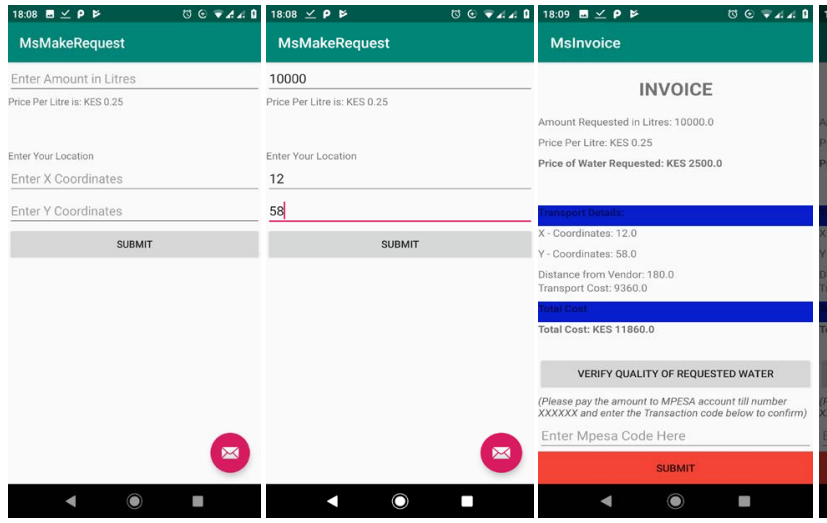

(a) (b)

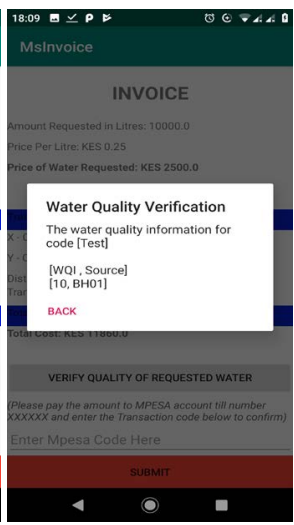

(d)

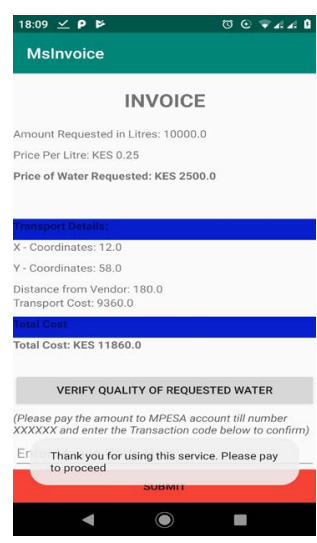

(e)

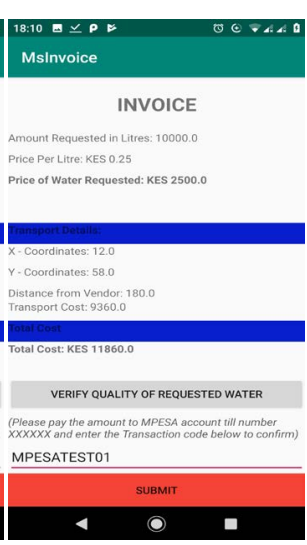

(f)

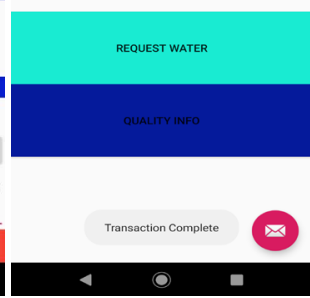

(g)

Figure 6. (a)-(d) Water delivery ordering process; (e)-(g) Water delivery ordering process. 


\section{Conclusion}

The application result of the developed app illustrates the possibility of having a connection between vendors and customers without the problem of dealing with unverified water sources. It can be inferred that with the quality verification made possible using Maji Safi app, informal water consumers will have a greater level of trust in water sourced from vendors and will thus freely source for water, including for drinking purposes. This then gives the answer to the main objective of the study. Given that previous systems that relied on word of mouth have not given the required level of trust, this app is a welcome solution to the entrenched quality mistrust in the vendor water market.

\section{Recommendations}

The water vendor system and water source module has yet to be created. Equally; the server functions for automated allocation of vendor to customer have yet to be done. The coordinate system is lacking and use of geo-location services, such as Google Maps, to automatically generate a user's location would be an added improvement to the system. These will require additional work. Use of block-chain is meant to further enhance the trust in the system especially with respect to consumer-vendor and consumer-source trust. This will require a collaborative framework between technology provider and water service players.

\section{Acknowledgements}

The authors are grateful for the support extended by the management of the Institute for Climate Change \& Adaptation of the University of Nairobi.

\section{Conflicts of Interest}

This research study has received no financial support from any quarters; as such none of the authors has any attached interest.

\section{References}

[1] Stigler, G. (1968) The Economics of Information. Journal of Political Economy, 69, 213-225.

[2] Nelson, P. (1970) Information and Consumer Behavior. Journal of Political Economy, 78, 311-329. https://doi.org/10.1086/259630

[3] Hanson, R. (1999) Decision Markets. IEEE Intelligent Systems, 14, 16-19. https://doi.org/10.1109/MIS.1999.757625

[4] Homans, G.C. (1958) Social Behavior as Exchange. American Journal of Sociology, 63, 597-606. https://doi.org/10.1086/222355

[5] Kirmani, A. and Rao, A.R. (2000) No Pain, No Gain: A Critical Review of the Literature on Signaling Unobservable Product Quality. Journal of Marketing, 64, 66-79. https://doi.org/10.1509/jmkg.64.2.66.18000

[6] Rees, A. (1966) Information Networks in Labor Markets. American Economic Review, 56, 559-566.

[7] Anderson, D.A. and Hamori, S. (2000) A Theory of Quality Signaling in the Mar- 
riage Market. Japan and the World Economy, 12, 229-242.

https://doi.org/10.1016/S0922-1425(00)00040-2

[8] Bagnoli, M. and Bergstom, T.C. (1973) Courtship as a Waiting Game. Journal of Political Economy, 101, 185-202. https://doi.org/10.1086/261871

[9] Becker, G.S. (1973) A Theory of Marriage: Part I. Journal of Political Economy, 81, 813-846. https://doi.org/10.1086/260084

[10] Becker, G.S. (1973) A Theory of Marriage: Part II. Journal of Political Economy, 82, 511-526. https://doi.org/10.1086/260287

[11] Becker, G.S. (1981) A Treatise on the Family. Harvard University Press, Cambridge.

[12] Zahavi, A. (1975) Mate Selection-A Selection for a Handicap. Journal of Theoretical Biology, 53, 205-214. https://doi.org/10.1016/0022-5193(75)90111-3

[13] Griffin, D.R. (1958) Listening in the Dark. Yale University Press, New Haven.

[14] Fenton, et al. (1995) Signal Strength, Timing, and Self-Deafening: The Evolution of Echolocation in Bats. Paleobiology, 21, 229-242.

https://doi.org/10.1017/S0094837300013221

[15] (2007). Experience and Credence Goods-An Introduction. In: Strategies in Markets for Experience and Credence Goods, Deutscher Universitäts-Verlag, Wiesbaden, 1-5.

[16] Eliashberg, J. and Robertson, T.S. (1988) New Product Pre-Announcing Behavior: A Market Signaling Study. Journal of Marketing Research, 25, 282. https://doi.org/10.2307/3172530

[17] Gambetta, D. (2009) Signaling. In: Hedström, P. and Bearman, P., Eds., The Oxford Handbook of Analytical Sociology, Oxford University Press, Oxford, 168-194.

[18] Cheshire, C., Gerbasi, A. and Cook, K.S. (2010) Trust and Transitions in Modes of Exchange. Social Psychology Quarterly, 73, 176-195. https://doi.org/10.1177/0190272509359615

[19] Przepiorka, W. and Berger, J. (2017) Signaling Theory Evolving: Signals and Signs of Trustworthiness in Social Exchange. In: Jann, B. and Przepiorka, W., Eds., Social Dilemmas, Institutions, and the Evolution of Cooperation, De Gruyter Oldenbourg, Berlin, 1-26. https://doi.org/10.1515/9783110472974-018

[20] Martín, S.S. and Camarero, C. (2005) Consumer Reactions to Firm Signals in Asymmetric Relationships. Journal of Service Research, 8, 79-97. https://doi.org/10.1177/1094670504273967

[21] Pitchik, C. and Schotter, A. (1993) Information Transmission in Regulated Markets. Canadian Journal of Economics, 26, 815-829. https://doi.org/10.2307/135822

[22] Akerlof, G.A. (1970) The Market for “Lemons": Quality Uncertainty and the Market Mechanism. The Quarterly Journal of Economics, 84, 488. https://doi.org/10.2307/1879431

[23] Spence, A.M. (1973) Job Market Signaling, Quarterly Journal of Economics, 87, 355-374. https://doi.org/10.2307/1882010

[24] Doria, M. (2010) Factors Influencing Public Perception of Drinking Water Quality. Water Policy, 12, 1-19. https://doi.org/10.2166/wp.2009.051

[25] Agensi, A., Tibyangye, J., Tamale, A., Agwu, E. and Amongi, C. (2019) Contamination Potentials of Household Water Handling and Storage Practices in Kirundo Subcounty, Kisoro District, Uganda. Journal of Environmental and Public Health, 2019, Article ID: 7932193. https://doi.org/10.1155/2019/7932193

[26] Gelt, J. (1996) Consumers Increasingly Use Bottled Water, Home Water Treatment 
Systems to Avoid Direct Tap Water. Arroyo, 9, 1-11.

[27] Chaidez, C., Rusin, P., Naranjo, J. and Gerba, C.P. (1999) Microbiological Quality of Water Vending Machines. International Journal of Environmental Health Research, 9, 197-206. https://doi.org/10.1080/09603129973164

[28] Lund, J., Medellin-Azuara, J., Durand, J. and Stone, K. (2018) Lessons from California's 2012-2016 Drought. Journal of Water Resources Planning and Management, 144, Article ID: 04018067. https://doi.org/10.1061/(ASCE)WR.1943-5452.0000984

[29] Zeraebruk, K.N., Mayabi, A.O., Gathenya, J.M. and Tsige, Z. (2014) Assessment of Water Supply Services and Operational Performance of Asmara Water Supply Department (AWSD) for Development of Decision Support Tools. Environment and Natural Resources Research, 4, 208-222. https://doi.org/10.5539/enrr.v4n4p208

[30] Brown, C. and Heller, L. (2017) Affordability in the Provision of Water and Sanitation Services: Evolving Strategies and Imperatives to Realize Human Rights. International Journal of Water Governance, 5, 19-38.

[31] Gonzales, P. and Ajami, N.K. (2019) Goal-Based Water Trading Expands and Diversifies Supplies for Enhanced Resilience. Nature Sustainability, 2, 138-147. https://doi.org/10.1038/s41893-019-0228-Z

[32] Liddle, E.S., Mager, S.M. and Nel, E.L. (2014) The Importance of Community-Based Informal Water Supply Systems in the Developing World and the Need for Formal Sector Support. The Geographical Journal, 182, 85-96.

https://doi.org/10.1111/geoj.12117

[33] Dakyaga, F., Kyessi, A.G. and Msami, J.M. (2018) Water Access Today and Tomorrow: Domestic Water Sustainability under Informal Water Supply Markets in Dar es Salaam, Tanzania. Journal of Sustainable Development, 11, 120-124. https://doi.org/10.5539/jsd.v11n6p120

[34] Tabotabo-Picardal, et al. (2018) Drinking Water Quality from Water Vending Machines in Selected Public Schools in Cebu City, Philippines. International Journal on Environmental Science and Sustainable Development, 3, 1-9. https://doi.org/10.21625/essd.v3iss1.253

[35] Venkatachalam, L. (2014) Informal Water Markets and Willingness to Pay for Water: A Case Study of the Urban Poor in Chennai City, India. International Journal of Water Resources Development, 31, 134-145. https://doi.org/10.1080/07900627.2014.920680

[36] Meran, G., Siehlow, M. and von Hirschhausen, C. (2018) Pipes, Taps and Vendors: Managing and Regulating the Unconnected Water Market, Beiträge zur Jahrestagung des Vereins für Socialpolitik 2018: Digitale Wirtschaft-Session: Environmental Economics IV, No. D06-V1, ZBW-Leibniz-Informationszentrum Wirtschaft, Kiel, Hamburg.

[37] Takala, A. and Heino, O. (2017) Weak Signals and Wild Cards in Water and Sanitation Services-Exploring an Approach for Water Utilities. European Journal of Futures Research, 5, 4. https://doi.org/10.1007/s40309-017-0111-y

[38] Hirshleifer, J. (1971) The Private and Social Value of Information and the Reward for Inventive Activity. American Economic Review, 61, 561-574.

[39] Fosdick, R.B. (1916) Passing of the Bertillon System of Identification. Journal of American Institute of Criminal Law and. Criminology, 6, 363-369. https://doi.org/10.2307/1132744

[40] Farebrother, R. and Champkin, J. (2014) Alphonse Bertillon and the Measure of Man: More Expert than Sherlock Holmes. Significance, 11, 36-39. 
https://doi.org/10.1111/j.1740-9713.2014.00739.x

[41] Buda, et al. (2018) Bertillonage and Criminal Anthropology in Bucharest, 1893. Romanian Journal of Legal Medicine, 26, 209-211.

[42] Davies, J., German, D.M., Godfrey, M.W. and Hindle, A. (2011) Software Bertillonage. Proceeding of the 8 th Working Conference on Mining Software Repositories, Waikiki, 21-22 May 2011, 183-192. https://doi.org/10.1145/1985441.1985468

[43] Ainuson, K.G. (2010) Urban Water Politics and Water Security in Disadvantaged Urban Communities in Ghana. African Studies Quarterly, 11, 59-82.

[44] Jin, G.Z. and Leslie, P. (2003) The Effect of Information on Product Quality: Evidence from Restaurant Hygiene Grade Cards. The Quarterly Journal of Economics, 118, 409-451. https://doi.org/10.1162/003355303321675428

[45] Dai, W. and Luca, M. (2018) Digitizing Disclosure: The Case of Restaurant Hygiene Scores. Harvard Business School Working Paper, No. 18-088. https://doi.org/10.2139/ssrn.3131900

[46] Roberts, A. (2006) Blacked Out: Government Secrecy in the Information Age. Cambridge University Press, Cambridge. https://doi.org/10.1017/CBO9781139165518

[47] Fung, A., Graham, M. and Weil, D. (2007) Full Disclosure: The Perils and Promise of Transparency. Cambridge University Press, Cambridge. https://doi.org/10.1017/CBO9780511510533

[48] Milgrom, P.R. (1981) Good News and Bad News: Representation Theorems and Applications. Bell Journal of Economics, 12, 380-391. https://doi.org/10.2307/3003562

[49] Steele, S., Ruskin, G., McKee, M. and Stuckler, D. (2019) "Always Read the Small Print": A Case Study of Commercial Research Funding, Disclosure and Agreements with Coca-Cola. Journal of Public Health Policy, 40, 273-285. https://doi.org/10.1057/s41271-019-00170-9

[50] Matthews, S. and Postlewaite, A. (1985) Quality Testing and Disclosure. The RAND Journal of Economics, 16, 328-340. https://doi.org/10.2307/2555561

[51] Fishman, M.J. and Hagerty, K.M. (2003) Mandatory versus Voluntary Disclosure in Markets with Informed and Uninformed Customers. Journal of Law, Economics, and Organization, 19, 45-63. https://doi.org/10.1093/jleo/19.1.45

[52] Dranove, D. and Jin, G.Z. (2010) Quality Disclosure and Certification: Theory and Practice. Journal of Economic Literature, 48, 935-963. https://doi.org/10.1257/jel.48.4.935

[53] Bacharach, M. and Gambetta, D. (2003) Trust in Signs. In: Cook, K.S., Ed., Trust in Society, Russell Sage, New York, 3-39.

[54] Bar-Gill, O. and Porat, A. (2017) Disclosure Rules in Contract Law. Coase-Sandor Working Paper Series in Law and Economics. 829.

https://chicagounbound.uchicago.edu/law_and_economics/829 https://doi.org/10.2139/ssrn.2985115

[55] Viscusi, W.K. (1978) A Note on "Lemons" Markets with Quality Certification. The Bell Journal of Economics, 9, 277-279. https://doi.org/10.2307/3003627

[56] Grossman, S.J. and Hart, O.D. (1980) Disclosure Laws and Takeover Bids. Journal of Finance, 35, 323-334. https://doi.org/10.1111/j.1540-6261.1980.tb02161.x

[57] Connelly, B.L., Certo, S.T., Ireland, R.D. and Reutzel, C.R. (2010) Signaling Theory: A Review and Assessment. Journal of Management, 37, 39-67. https://doi.org/10.1177/0149206310388419 
[58] Baier, A. (1994) Moral Prejudices. Harvard University Press, Cambridge.

[59] Aleichem, S. (1969) The Adventures of Menahem-Mendl, Trans. Tamara Kahana. G. P. Putnam's Sons, New York.

[60] Newman, S. and Hutton-Yeo, A. (2008) Intergenerational Learning and the Contributions of Older People. Ageing Horizons, 8, 31-39.

[61] Brenner, R. (1979) Human Capital and Changing Circumstances. The Workshop in Applications of Economics, Chicago, IL, 3-5 May 1979.

[62] Biernaskie, J.M., Grafen, A. and Perry, J.C. (2014) The Evolution of Index Signals to Avoid the Cost of Dishonesty. Proceedings of the Royal Society B: Biological Sciences, 281, pii: 20140876. https://doi.org/10.1098/rspb.2014.0876

[63] Pitchik, C. and Schotter, A. (1987) Honesty in a Model of Strategic Information Transmission. American Economic Review, 77, 1032-1036.

[64] Monroe, K.B. (1973) Buyers' Subjective Perceptions of Price. Journal of Marketing Research, 10, 70. https://doi.org/10.2307/3149411

[65] Farrell, J. (1980) Prices as Signals of Quality. Ph.D. Thesis, University of Oxford, Oxford.

[66] Wolinsky, A. (1983) Prices as Signals of Product Quality. Review of Economic Studies, 50, 647-658. https://doi.org/10.2307/2297767

[67] Gerstner, E. (1985) Do Higher Prices Signal Higher Quality? Journal of Marketing Research, 22, 209-215. https://doi.org/10.1177/002224378502200210

[68] Tellis, G.J. and Wernerfelt, B. (1987) Competitive Price and Quality under Asymmetric Information. Marketing Science, 6, 240-253. https://doi.org/10.1287/mksc.6.3.240

[69] Zeithaml, V.A. (1988) Consumer Perceptions of Price, Quality and Value: A Means End Model and Synthesis of Evidence. Journal of Marketing, 52, 2-22. https://doi.org/10.1177/002224298805200302

[70] Bagwell, K. and Riordan, M.H. (1991) High and Declining Prices Signal Product Quality. American Economic Review, 81, 224-239.

[71] Milgrom, P. and Roberts, J. (1986) Price and Advertising Signals of Product Quality. Journal of Political Economy, 94, 796-821. https://doi.org/10.1086/261408

[72] Sahni, N.S. and Nair, H.S. (2016) Does Advertising Serve as a Signal? Evidence from Field Experiments in Mobile Search. https://doi.org/10.2139/ssrn.2721468

[73] Tsui, H.-C. (2012) Advertising, Quality, and Willingness-to-Pay: Experimental Examination of Signaling Theory. Journal of Economic Psychology, 33, 1193-1203. https://doi.org/10.1016/j.joep.2012.08.011

[74] Glazer, J. and Mcguire, T. (1993) The Economics of Referrals. IIBR Working Paper No. 31/93, Tel Aviv University, Tel Aviv.

[75] Van Den Bulte, C., Bayer, E., Skiera, B. and Schmitt, P. (2018) How Customer Referral Programs Turn Social Capital into Economic Capital. Journal of Marketing Research, 55, 132-146. https://doi.org/10.1509/jmr.14.0653

[76] Cramer, C., Johnston, D., Mueller, B., Oya, C. and Sender, J. (2016) Fairtrade and Labour Markets in Ethiopia and Uganda. The Journal of Development Studies, 53, 841-856. https://doi.org/10.1080/00220388.2016.1208175

[77] Bonroy, O. and Constantatos, C. (2008) On the Use of Labels in Credence Goods Markets. Journal of Regulatory Economics, 33, 237-252. https://doi.org/10.1007/s11149-008-9058-Z

[78] Wernerfelt, B. (1988) Umbrella Branding as a Signal of New Product Quality: An 
Example of Signalling by Posting a Bond. The RAND Journal of Economics, 19, 458. https://doi.org/10.2307/2555667

[79] Lizzeri, A. (1999) Information Revelation and Certification Intermediaries. The RAND Journal of Economics, 30, 214-231. https://doi.org/10.2307/2556078

[80] Auriol, E. and Schilizzi, S. (2001) Quality Signaling through Certification: Theory and an Application to Agricultural Seed Markets. Mimeo IDEI Toulouse.

[81] Stahl, K. and Strausz, R. (2017) Certification and Market Transparency. The Review of Economic Studies, 84, 1842-1868.

[82] Mason, C. (2011) Eco-Labeling and Market Equilibria with Noisy Certification Tests. Environmental and Resource Economics, 48, 537-560. https://doi.org/10.1007/s10640-010-9402-5

[83] Mishra, D.P., Heide, J.B. and Cort, S.G. (1998) Information Asymmetry and Levels of Agency Relationships. Journal of Marketing Research, 35, 277. https://doi.org/10.2307/3152028

[84] Bolton, P. and Dewatripont, M. (2005) Contract Theory. MIT Press, Cambridge.

[85] Chan, T., Murphy, A. and Wang, L. (2018) Information Asymmetry, Manufacturer-Retailer Contracts, and Two-Sided Entry. International Economic Review, 59, 2163-2191. https://doi.org/10.1111/iere.12333

[86] Biglaiser, G. and Li, F. (2018) Middlemen: The Good, the Bad, and the Ugly. The RAND Journal of Economics, 49, 3-22. https://doi.org/10.1111/1756-2171.12216

[87] Nastiti, A., Muntalif, B.S., Roosmini, D., Sudradjat, A., Meijerink, S.V. and Smits, A.J.M. (2017) Coping with Poor Water Supply in Peri-Urban Bandung, Indonesia: Towards a Framework for Understanding Risks and Aversion Behaviours. Environment and Urbanization, 29, 69-88. https://doi.org/10.1177/0956247816686485

[88] Michaelidou, N. and Hassan, L.M. (2008) The Role of Health Consciousness, Food Safety Concern and Ethical Identity on Attitudes and Intentions towards Organic Food. International Journal of Consumer Studies, 32, 163-170.

https://doi.org/10.1111/j.1470-6431.2007.00619.x

[89] Vollmer Dahlke, D., Fair, K., Hong, Y.A., Beaudoin, C.E., Pulczinski, J. and Ory, M.G. (2015) Apps Seeking Theories: Results of a Study on the Use of Health Behavior Change Theories in Cancer Survivorship Mobile Apps. JMIR mHealth and uHealth, 3, e31. https://doi.org/10.2196/mhealth.3861

[90] Mustafa, D. and Talozi, S. (2018) Tankers, Wells, Pipes and Pumps: Agents and Mediators of Water Geographies in Amman, Jordan. Water Alternatives, 11, 916-932.

[91] Ahmad, M.T. (2016) The Role of Water Vendors in Water Service Delivery in Developing Countries: A Case of Dala Local Government, Kano, Nigeria. Applied Water Science, 7, 1191-1201. https://doi.org/10.1007/s13201-016-0507-Z

[92] Akpe, A. (2011) Nigeria: Brisk Water Business. https://pulitzercenter.org/reporting/nigeria-brisk-water-business

[93] Ayalew, M., Chenoweth, J., Malcolm, R., Mulugetta, Y., Okotto, L.G. and Pedley, S. (2013) Small Independent Water Providers: Their Position in the Regulatory Framework for the Supply of Water in Kenya and Ethiopia. Journal of Environmental Law, 26, 105-128. https://doi.org/10.1093/jel/eqt028

[94] Chauhan, A., Goyal, P., Varma, A. and Jindal, T. (2015) Microbiological Evaluation of Drinking Water Sold by Roadside Vendors of Delhi, India. Applied Water Science, 7, 1635-1644. https://doi.org/10.1007/s13201-015-0315-x

[95] Hajli, N. (2014) A Study of the Impact of Social Media on Consumers. International Journal of Market Research, 56, 388-404. 
https://doi.org/10.2501/IJMR-2014-025

[96] Tewatia, et al. (2017) App-Based Water Tanker Booking, Monitoring and Controlling System. International Journal of Science Technology and Engineering, 3, 238-248.

[97] Andrici, M. (2012) mWater Is an Android App That Tracks Water Quality Results, Could Save Plenty of Lives.

https://www.androidauthority.com/mwater-android-app-112206

[98] Jamaluddin, A., Harjunowibowo, D., Rahardjo, D.T., Adhitama, E. and Hadi, S. (2016) Wireless Water Flow Monitoring Based on Android Smartphone. 2nd International Conference of Industrial, Mechanical, Electrical, and Chemical Engineering, Yogyakarta, 6-7 October 2016, 243-247.

https://doi.org/10.1109/ICIMECE.2016.7910449

[99] Kaleel, S.B. and Harishankar, S. (2013) Applying Agile Methodology in Mobile Software Engineering: Android Application Development and Its Challenges. Computer Science Technical Reports. Paper 4.

http://digitalcommons.ryerson.ca/compsci_techrpts/4 